\title{
MAKNA KONFLIK PERAN PADA MAHASISWA DENGAN PERAN GANDA
}

\author{
Ervin Nurul Afrida \\ Fakultas Psikologi, Universitas Airlangga \\ email:ervin.nurul.affrida-2015@psikologi.unair.ac.id
}

\begin{abstract}
This study aims to understand phase of conflict and purpose in students with multiple roles. The research method used qualitative method with phenomenological approach. Data collection technique are in depth interviews. Data analysis technique used Interpretative Phenomenological Analysis (IPA). Member check as stabilization techniques credibility.

The result about phase of role conflict include role conflict caused by the imbalance division of time between roles. Then, role conflict caused of behavior not consistent with role purpose. Role conflicts in students with multiple roles interpreted by still work and carry out tasks with the involvement and responsibility on multiple roles followed, and taking a stand against conflict of roles, while still working on academic assignments and teaching obligations despite the tendency to experience role conflict. Based this result can be concluded that the conflicting positions on the role of a student with a dual role is interpreted differently depending on the perception of each individual.
\end{abstract}

Keywords :Meaningfullness, Role Conflict, Students With Dual Role

\section{PENDAHULUAN}

Peran didefinisikan sebagai gambaran perilaku dalam melaksanakan hak dan kewajiban sesuai dengan kedudukannya (Johnson \& Johnson, 2000). Kedudukan dan peran perempuan dipengaruhi oleh perubahan sosial yang terbentuk melalui sistem sosial dan budaya di masyarakat. Perubahan sosial diartikan sebagai pergeseran sikap dan perilaku dari faktor-faktor ekologis dan demografis yang mengubah kehidupan masyarakat dari kondisi tradisional menuju masyarakat modern. Salah satu perubahan sosial di masyarakat adalah pergeseran peran perempuan melalui faktor-faktor sosial dan budaya yang berorientasi gender

Gender merupakan pembedaan peran, identitas, serta hubungan antara perempuan dan laki-laki sebagai hasil bentukan masyarakat (Fakih, 1996). Oleh karena itu, individu yang berjenis kelamin perempuan cenderung melakukan seperangkat peran yang biasa dilakukan perempuan, begitu pula sebaliknya pada laki-laki. Salah satu pandangan tradisional peran perempuan adalah masak, macak, manak (memasak, bersolek, melahirkan anak) (Fakih, 1996). Berdasarkan pandangan tradisional tersebut, peran perempuan ditentukan oleh kemampuannya sebagai pengurus rumah tangga dan sebagai istri.
Adanya perkembangan ilmu pengetahuan dan teknologi, mendorong perempuan yang telah menikah untuk mengakses peran-peran di sektor publik. Adapun salah satu bentuk akses perempuan yang telah menikah dalam bentuk menempuh pendidikan tinggi. Mahasiswa perempuan yang berstatus menikah disebut sebagai mahasiswa dengan peran ganda. Menurut Rustiani (1996), peran ganda merupakan dua peran atau lebih pada peran domestik dan publik yang dijalankan dalam waktu yang bersamaan (Rustiani, 1996). Adanya keinginan perempuan dalam menjalankan peran domestik di keluarga dan peran publik dapat menimbulkan kecenderungan konflik peran (Sadli, dalam Fitri, 2000). Konflik peran didefinisikan sebagai suatu bentuk konflik yang muncul antar peranan karena adanya peran ganda (Greenhaus \& Beutell, 1985). Gambaran konflik peran pada mahasiswa dengan peran ganda tercantum dalam beberapa hasil penelitian, salah satunya penelitian Malhotra dan Sachdeva (2005) yang menunjukkan adanya pengaruh signifikan antara perempuan yang bekerja dengan munculnya konflik peran. Hasil penelitian Ruslina (2014) juga menunjukkan bahwa peran ganda menimbulkan kecenderungan terjadinya konflik peran. Penelitian Luluk (2015) menunjukkan hasil bahwa mahasiswi yang 
telah menikah memiliki tanggung jawab pada peran domestik dan publik sehingga rentan terjadinya konflik antar peran.

Kajian tentang penyebab munculnya konflik peran tercantum dalam hasil penelitian Couzy (2012) yang menunjukkan bahwa kurangnya waktu sebagai penyebab terjadinya konflik peran. Hasil penelitian tersebut sesuai dengan pendapat Yang., dkk (2000) bahwa salah satu faktor yang mempengaruhi terjadinya konflik peran adalah time based conflict, yaitu konflik peran karena waktu yang digunakan untuk memenuhi satu peran dapat mengurangi waktu untuk memenuhi kebutuhan peran lainnya. Berdasarkan kajian dari beberapa penelitian sebelumnya, diperoleh gambaran awal bahwa mahasiswa dengan peran ganda memiliki kecenderungan mengalami konflik peran. Penelitian ini akan mengkaji bentuk-bentuk konflik peran dan makna terhadap konflik peran pada mahasiswa dengan peran ganda.

\section{TINJAUAN TEORITIS}

Peran ganda disebut dengan konsep dualisme cultural yaitu adanya konsep domestik sphere (lingkungan domestik) dan publik sphere (lingkungan publik) (Michele \& Louise, 1974). Dalam penelitian ini, peran ganda ditinjau berdasarkan peran perempuan sebagai mahasiswa, peran sebagai istri dan ibu rumah tangga, dan peran perempuan sebagai wanita karir. Secara etimologi, konflik berasal dari bahasa latin yaitu configere. Konflik sebagai suatu hal alami dan normal yang muncul karena perbedaan persepsi, tujuan atau nilai (Scannell, 2010). Konflik peran ganda merupakan konflik yang muncul akibat tekanan-tekanan yang berasal dari peran ganda (Greenhouse \& Beutell, 1985). Bentuk-bentuk konflik peran meliputi: (1) Time based conflict, konflik peran karena waktu yang digunakan untuk memenuhi satu peran dapat mengurangi waktu untuk memenuhi kebutuhan peran lainnya; (2) Strain based conflict, konflik peran karena adanya tekanan dari salah satu peran mempengaruhi kinerja peran lainnya; (3) Behaviour based conflict, konflik peran karena adanya ketidaksesuaian antara pola perilaku dengan tujuan yang diinginkan dari peran ganda tersebut (Greenhaus \& Beutell, 1985).

Pemaknaan terhadap konflik peran ganda menarik untuk diteliti, karena setiap mahasiswa dengan peran ganda mempunyai pengalaman konflik peran yang berbeda-beda, sehingga konflik tersebut juga dimaknai berbeda-beda antar mahasiswa. Makna merupakan bagian tertinggi dari hirarki kebutuhan manusia yang dikenal dengan aktualisasi diri (Maslow, 1954). Makna hidup merupakan hal-hal yang dianggap sangat penting dan berharga, serta memberikan nilai khusus bagi individu, sehingga menjadi tujuan dalam kehidupan (the purpose of life) (Bastaman, 2007). Frankl (dalam Schultz, 1991) menyatakan bahwa makna hidup terwujud dalam nilai-nilai kreatif, nilai-nilai pengalaman, dan nilai-nilai sikap yang menimbulkan perasaan bahagia dan berarti dalam kehidupan. Kajian terhadap makna konflik peran dapat memberikan manfaat untuk memahami bentuk-bentuk konflik peran serta maknanya bagi mahasiswa dengan peran ganda. Dengan pemahaman tersebut, diharapkan dapat berimplikasi pada bentukbentuk perilaku mahasiswa untuk mencegah kecenderungan munculnya konflik peran ganda.

\section{METODE PENELITIAN}

Penelitian ini dilakukan dengan menggunakan metode kualitatif, melalui pendekatan fenomenologi. Tujuan dalam penelitian ini adalah untuk memahami bentuk dan makna konflik peran pada mahasiswa dengan peran ganda. Informan penelitian sebanyak 3 orang mahasiswa Program Pascasarjana di Universitas " $\mathrm{X}$ " Surabaya. Teknik penggalian data melalui wawancara mendalam in depth interview yang dianalisis menggunakan

Interpretative Phenomenological Analyisis (IPA). Teknik pemantapan kredibilitas penelitian menggunakan member checking.

\section{HASIL DANPEMBAHASAN}

Hasil dalam penelitian ini terdiri dari (1) Bentuk-bentuk konflik peran pada mahasiswa dengan peran ganda; dan (2) Makna konflik peran pada mahasiswa dengan peran ganda. Hasil temuan penelitian akan dijelaskan sebagai berikut:

\section{Informan 1}

Informan 1 merupakan mahasiswa Program Pascasarjana semester 3 yang berstatus menikah dan bekerja sebagai guru di SMP "X" di kota Surabaya. Hasil temuan penelitian menunjukkan bahwa konflik peran yang dialami informan 1 adalah time based conflict, yaitu konflik peran yang disebabkan tidak seimbangnya pembagian waktu untuk mencukupi kebutuhan antar peran. Pembagian 
waktu menjadi penyebab munculnya konflik peran karena informan 1 merupakan guru di fullday school dengan jam kerja dari pukul 07.00 hingga 16.00 WIB. Konflik peran muncul karena waktu yang digunakan informan mendominasi pada pemenuhan kebutuhan peran sebagai guru, sehingga kurang adanya waktu untuk memnuhi kebutuhan peran sebagai mahasiswa dan ibu rumah tangga. Konflik peran karena kurang seimbangnya pembagian waktu dimaknai informan sebagai nilai-nilai kreatif (creative values), karena konflik yang muncul dimaknai individu melalui bekerja serta melaksanakan tugas dengan keterlibatan dan tanggung jawab pada peran ganda yang dijalani

\section{Informan 2}

Informan 2 merupakan mahasiswa Program Pascasarjana semester 5 yang berstatus menikah dan bekerja sebagai trainer di lembaga bimbingan belajar di kota Surabaya. Hasil temuan penelitian menunjukkan bahwa konflik peran yang dialami informan 1 adalah behaviour based conflict, yaitu konflik peran karena adanya ketidaksesuaian antara pola perilaku dengan tujuan yang diinginkan dari peran ganda tersebut dan time based conflict, yaitu konflik peran karena waktu yang digunakan untuk memenuhi satu peran dapat mengurangi waktu untuk memenuhi kebutuhan peran lainnya. Ketidaksesuaian perilaku menjadi penyebab munculnya konflik peran karena informan 2 mengalami konflik pada perilaku-perilaku maladaptif yang tidak sesuai dengan tujuan yang telah ditetapkan. Perilaku penundaan terhadap tugas akademik merupakan perilaku yang muncul sehingga menimbulkan konflik terhadap pemenuhan kebutuhan peran sebagai mahasiswa. Konflik tersebut muncul berupa penghambatan masa studi informan 2. Selain itu, pembagian waktu juga menjadi penyebab munculnya konflik peran. Hal ini disebabkan, waktu yang digunakan informan lebih mendominasi untuk pemenuhan kebutuhan peran sebagai trainer. Tidak seimbangnya pembagian waktu tersebut, menyebabkan pemenuhan kebutuhan peran sebagai mahasiswa mengalami hambatan, yaitu keterlambatan lulus studi. Informan 2 memaknai konflik yang terjadi sebagai nilainilai sikap, yang diperoleh individu dengan mengambil sikap terhadap konflik peran yang tidak bisa dihindari. Nilai ini menekankan bahwa permasalahan yang dialami individu masih dapat memberikan makna bagi dirinya jika disikapi dengan tepat.

\section{Informan 3}

Informan merupakan mahasiswa Program Pascasarjana semester 5 yang berstatus menikah dan bekerja sebagai guru di salah satu SMA di kota Surabaya. Hasil temuan penelitian menunjukkan bahwa konflik peran yang dialami informan 3 adalah time based conflict, yaitu konflik peran karena waktu yang digunakan untuk memenuhi satu peran dapat mengurangi waktu untuk memenuhi kebutuhan peran lainnya. Pembagian waktu menjadi penyebab munculnya konflik peran karena informan menggunakan waktunya untuk memenuhi kebutuhan peran domestik sebagai ibu, dengan mengasuh 2 orang anak dalam usia balita. Ketidakseimbangan pembagian waktu tersebut menimbulkan konflik keterlambatan lulus studi dan terbengkalainya tugas di tempat kerja. Informan 3 memaknai konflik yang terjadi sebagai nilai-nilai sikap, yang diperoleh individu dengan mengambil sikap terhadap konflik peran yang tidak bisa dihindari. Informan menyikapi permasalahan dengan tetap mengerjakan tugas-tugas akademik dan kewajiban mengajar meskipun kurang maksimal.

\section{KESIMPULAN}

Berdasarkan hasil penelitian, dapat disimpulkan bahwa konflik peran yang dialami pada mahasiswa dengan peran ganda berbeda-beda. Adanya perbedaan bentuk konflik peran ganda tersebut, menyebabkan perbedaan pula pada pemaknaan terhadap konflik peran. Adanya pemahaman terhadap makna konflik peran diharapkan dapat berimplikasi pada perilku-perilaku untuk mencegah dan mengatasi konflik peran.Sehingga saran untuk penelitian selanjutnya diharapkan menambahkan kajian lebih mendalam terhadap strategi yang digunakan mahasiswa dengan peran ganda untuk mnghadapi konflik peran ganda.

\section{REFERENSI}

Bastaman, H.D. (2007). Logoterapi: Psikologi untuk Menemukan Makna Hidup dan Meraih Hidup Bermakna. Jakarta: PT. Raja Grafindo.

Budiharjo, P. (1997). Mengenal Teori Kepribadian Mutakhir. Yogyakarta: Kanisius. 
Bosch, B. (2013). Women Who Study:Balancing The Dual Roles of Postgraduate Student and Mother. Edith Cowan University: Faculty of Computing, Health and Science.

Boyatzis, R.E. (1998). Transforming Qualitative Information: Thematic Analysis and Code Development. Sage Publication.

Couzy, M. (2012). Conflicting Roles: Balancing Family and Professional Life-a Chalengge for Working Women. Linnaeus University: Thesis School of Business and Economics.

Esson, P. L. (2004). Consequences of workfamily conflict: Testing a new model of work-related, non-work-related and stress-related outcomes. Thesis. The Faculty of the Virginia Polytechnic Institute and State University. Blacksburg, VA. Pp.1-101.

Fakih, M. (1996). Analisis Gender dan Transformasi Sosial. Yogyakarta: Pustaka Pelajar Offset.

Frankl, F.E. (1988). The Will to Meaning, Foundations and Applications of Logotherapy. New York: Meridian.

Greenhaus, J. H., \& Beutell, N. J. (1985). Sources of Conflict Between Work and Family Roles.Academy of Management ReviewVol. 10 N0. 1 76-88.

Johnson, D. W. \& Johnson, F. P. (2000). Joining Together: Group Theory and Group Skill. Pearson Education Company: New York.

Malhotra, S \&Sachdeva, S. (2005). Social Roles and Role Conflict: An Interprofessional Study among Women. Rohtak University: Journal of the Indian Academy of Applied Psychology, Volume. 31, No.1-2, 3742.

Ruslina. (2014). Hubungan Antara Konflik Peran Ganda Dengan Stres Kerja Pada Wanita Bekerja. Naskah Publikasi. Universitas Muhammadiyah Surakarta.

Streubert, H. J. \& Carpenter, D. R. (2011). Qualitative Research in Nursing Advancing the Humanistic Imperative, 5th. Philadephia: Lippincot William \& Wilkins A Wolters Kluwer Company.
Stoner, A.F. \& Charles, R. (1990). WorkHome Role Conflict in Female Owners of Small Business Management.

Smith, J. A., \& Osborn, M. (2007). Interpretative Phenomenological Analysis. In J. A. Smith (Ed.), Qualitative Psychology: Practical Guide to Research Method. London :SAGE Publications.

Thomas, J., Raynor, M., \& Al-Marzooqi, A. (2012). Marital Status and Gender as Predictors Of Undergraduate Academic Performance: a United Arab Emirates Context. Learning and Teaching in Higher Education: Gulf Perspectives (2). http://lthe.zu.ac.ae. 